\title{
Numerical simulations of mixing conditions and aerosol dynamics in the CERN CLOUD chamber
}

\author{
J. Voigtländer ${ }^{1}$, J. Duplissy ${ }^{2,3}$, L. Rondo ${ }^{4}$, A. Kürten ${ }^{4}$, and F. Stratmann ${ }^{1}$ \\ ${ }^{1}$ Leibniz Institute for Tropospheric Research, Leipzig, Germany \\ ${ }^{2}$ CERN, PH Department, Geneva, Switzerland \\ ${ }^{3}$ Department of Physics, University of Helsinki, P.O. Box 64, 00014 Helsinki, Finland \\ ${ }^{4}$ Institute for Atmospheric and Environmental Science, Goethe-University, Frankfurt/Main, Germany \\ Correspondence to: J. Voigtländer (jensv@tropos.de)
}

Received: 24 June 2011 - Published in Atmos. Chem. Phys. Discuss.: 14 July 2011

Revised: 26 January 2012 - Accepted: 16 February 2012 - Published: 29 February 2012

\begin{abstract}
To study the effect of galactic cosmic rays on aerosols and clouds, the Cosmics Leaving OUtdoor Droplets (CLOUD) project was established. Experiments are carried out at a $26.1 \mathrm{~m}^{3}$ tank at CERN (Switzerland). In the experiments, the effect of ionizing radiation on $\mathrm{H}_{2} \mathrm{SO}_{4}$ particle formation and growth is investigated. To evaluate the experimental configuration, the experiment was simulated using a coupled multidimensional computational fluid dynamics (CFD) - particle model. In the model the coupled fields of gas/vapor species, temperature, flow velocity and particle properties were computed to investigate mixing state and mixing times of the CLOUD tank's contents. Simulation results show that a 1-fan configuration, as used in first experiments, may not be sufficient to ensure a homogeneously mixed chamber. To mix the tank properly, two fans and sufficiently high fan speeds are necessary. The $1 / \mathrm{e}$ response times for instantaneous changes of wall temperature and saturation ratio were found to be in the order of few minutes. Particle nucleation and growth was also simulated and particle number size distribution properties of the freshly nucleated particles (particle number, mean size, standard deviation of the assumed log-normal distribution) were found to be distributed over the tank's volume similar to the gas species.
\end{abstract}

\section{Introduction}

Atmospheric aerosols are complicated multiphase systems, influencing Earth' climate directly via absorption and scattering of solar radiation and indirectly via cloud processes. Key parameters for physical and chemical behavior are microphysical properties, i.e., particle/droplet number size distribution and chemical composition of the particles. However, the processes, which control these properties are not well understood. Largest uncertainties in understanding the current climate change are attributed to aerosols and clouds (IPCC2007). These uncertainties partly result from solarrelated contributions and require further research. For example, still under discussion are galactic cosmic ray ionization effects on aerosols and clouds (e.g., Carslaw et al., 2002; Enghoff and Svensmark, 2008; Kirkby, 2007; Kulmala et al., 2010; Svensmark and Friis-Christensen, 1997).

To investigate quantitatively both, particle nucleation and the effects of ionisation on particle nucleation, the Cosmics Leaving OUtdoor Droplets (CLOUD) project was established. Within this project, experiments are carried out at a large volume cloud chamber $\left(26.1 \mathrm{~m}^{2}\right)$ located at CERN (Switzerland). The chamber has been carefully designed for carrying out experiments under very clean and thermodynamically stable conditions (Kirkby et al., 2011) and can be exposed to a particle beam provided by the CERN Proton Synchrotron (PS) particle accelerator. The particle beam is applied to create ions and to study their effect on aerosol particle formation and on cloud condensation nuclei and ice 


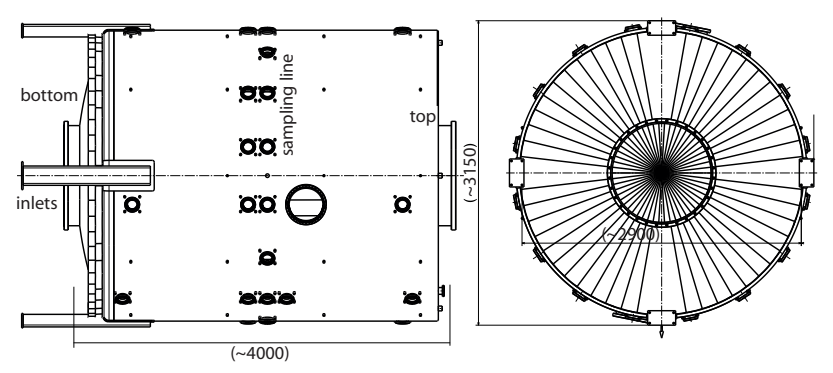

Fig. 1. Schematic diagram of the CLOUD chamber, a stainless steel cloud tank with $26.1 \mathrm{~m}^{3}$. According to the figures shown in the following, the front view of the tank was rotated by $90^{\circ}$ (clockwise). At the mid-height, the holes for the sampling probes (sampling line) are visible.

nuclei activation. The chamber is equipped with a large number of different instruments to study aerosol cloud cosmic rays micro physics under well defined conditions.

A big issue in large volume cloud chambers like the CLOUD chamber at CERN is to attain special homogeneity regarding the prevailing thermodynamic conditions, gas concentrations and particle properties. Achieving homogeneity inside the tank becomes even more challenging, if several parameters are changed during the experiments (e.g., via UVillumination system, particle nucleation, trace gas input, wall cooling). To ensure homogeneity, mixing fans are usually applied in such experiments. To check the mixing state, measurements are made at several selected points of the chamber. However, it is not possible to check all parameters continuously, and therefore numerical simulations are helpful and necessary.

A theoretical study concerning cloud droplet formation in a similar (shape, aspect ratio), but smaller $\left(12 \mathrm{~m}^{3}\right)$ cloud tank was already given by Schütze and Stratmann (2008). It was stated that a 2-fan configuration gives, with respect to homogeneity in the chamber, much better results than a 1-fan configuration. However, simulations presented in Schütze and Stratmann (2008) were not performed for the actual CLOUD geometry and not evaluated with experimental cloud chamber data.

This paper presents numerical simulation results for a cloud tank with the geometry of the CLOUD chamber concerning the mixing state with respect to both, gaseous species and particles. Simulations were carried out using a coupled computational fluid dynamics (CFD) - particle model called CLOUD-FPM. After a very brief description of the experimental set up, fundamental aspects of the simulations are given, followed by several model results in comparison to experimental data.
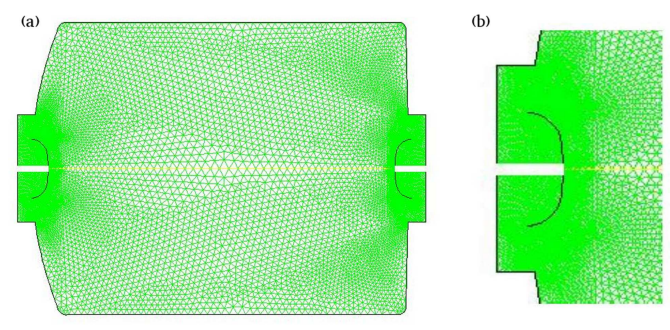

Fig. 2. (a) Numerical grid used for the CLOUD-FPM simulations. The grid has about 20000 grid cells and was generated according to the requirements of the turbulence model applied for the simulations. The thin lines next to the bottom and the top are representing the mixing fans and the small, not meshed areas in between are the fan hubs. The mixing fan layer is also shown in detail in (b).

\section{The CLOUD chamber}

The cylindrical CLOUD chamber, located at CERN, is an electro-polished stainless steel tank with a diameter of $3.0 \mathrm{~m}$, a height of approx. $4.0 \mathrm{~m}$ and a corresponding volume of $26.1 \mathrm{~m}^{3}$. The tank was designed, after a pilot experiment (Duplissy et al., 2010), with respect to achieve highest standards of cleanliness and temperature stability (Kirkby et al., 2011). A schematic diagram of the chamber is shown in Fig. 1. Different inlets and outlets at the chamber wall can be used to connect sampling probes, to introduce trace gases into the chamber, and to evacuate the chamber. To continuously mix the tank's contents, two fans can be installed next to the flanges at the top and the bottom (thin black lines in Fig. 2). At the top of the tank, there is also an UVillumination system (Kupc et al., 2011), illustrated in Fig. 3), which is used to trigger the $\mathrm{OH}$ production via ozone photolysis. The $\mathrm{OH}$ radicals then react with $\mathrm{SO}_{2}$ to form sulfuric acid $\left(\mathrm{H}_{2} \mathrm{SO}_{4}\right)$. Dependent on $\mathrm{H}_{2} \mathrm{SO}_{4}$ precursor concentrations, thermodynamic conditions and beam intensity, $\mathrm{H}_{2} \mathrm{SO}_{4}$ particle nucleation will occur (Kirkby et al., 2011).

\section{Numerical model}

\subsection{General remarks}

An important requirement for the experiments at the CLOUD chamber are well positioned sampling points and a tank's mixing state being as homogeneous as possible. In case of a non well-mixed chamber, the samples may not be representative for the whole tank. To evaluate the experimental configuration, the CLOUD chamber was simulated using the commercially available computational fluid dynamics (CFD) code FLUENT (ANSYS Inc., Canonsburg, PA, USA) together with the Fine Particle Model FPM, Particle Dynamics GmbH, Leipzig, Germany, Wilck et al., 2002). The FLUENT model allows the simulation of a wide range of small scale fluid problems, while the FPM was developed 


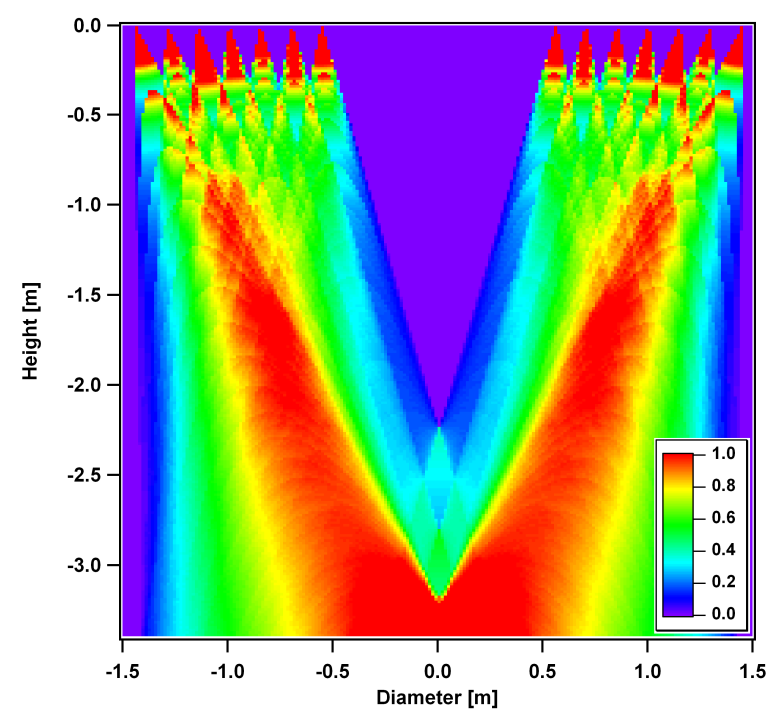

Fig. 3. UV illumination below $317 \mathrm{~nm}$ inside the CLOUD chamber (Kupc et al., 2011). In the numerical simulations, $\mathrm{H}_{2} \mathrm{SO}_{4}$ production was assumed to take place only in the parts of high UV intensity (red and yellow areas).

as a general purpose particle dynamics model. Both models together form the so-called CLOUD-FPM, a model being capable of handling the coupled fluid and particle dynamical processes taking place inside the CLOUD chamber. In CLOUD-FPM, all relevant properties like velocity, temperature, pressure, turbulence parameters, composition of gas/particle phase, and nucleation/growth of ultrafine aerosol particles are treated explicitly. The coupling of the models also includes the consideration of mass and heat transfer between gas and particle phase due to particle nucleation and condensational growth.

For the simulations, the geometry of the CLOUD chamber must be discretized on a numerical grid. Subsequently, the fluid and particle dynamics equations are solved on this grid. Because of the cylindrical geometry of the tank, a 2dimensional (2-D) axis-symmetric grid can be used to efficiently evaluate the mixing state. Compared to a 3-D treatment, such a grid reduces the computational costs significantly, although it is obvious that 2-D simulations do not allow a one to one description of the experimental set up. For example, individual holes (inlets/outlets) at the chamber bottom/side cannot be simulated using an axis-symmetric grid (bottom: if outside of the tank axis).

The flow field inside the chamber is of turbulent nature, even for small flow velocities in the order of few centimeters per second. Therefore, a k- $\epsilon$-turbulence-model (Jones and Launder, 1972; Launder and Spalding, 1973) with enhanced wall functions was applied. Utilizing such a near wall approach means that the laminar sublayer with a thickness of about $10^{0} \mathrm{~mm}$ has to be resolved by the numerical grid. Ac- cordingly, a grid with about 20000 grid cells (Fig. 2) was generated and applied for the simulations shown here.

\subsection{Mixing fans}

One of the key parameters in the numerical simulations is a proper description of the mixing fans. As simulations on a 2-D grid do not allow a consideration of the rotating fan blades, the fans are represented by zero thickness pressure jump layers (e.g. Fluent User's guide). The pressure jump $\delta_{p}$ across the fan plane is described by a polynomial function dependent on flow speed. To provide an accurate representation of the flow field, pressure jump and shape of the fan planes have to be adjusted to experimental flow field data. For this study this was done by a comparison with a radial velocity profile determined $50 \mathrm{~cm}$ above the bottom mixing fan in the CLOUD chamber.

The measured velocity profile compared to the simulated one is shown in Fig. 4. Experimental data for a 1-fan configuration (no hood, CLOUD-1) are represented by the black dots (Fig. 4a), data for the current 2-fan configuration (CLOUD5) are given by the blue curves (Fig. 4b). Figure 4a shows that 2-D simulations with the simplest approach of a flat disc shaped fan layer are not suitable to reproduce the experimental data. The simulated jet above the fan (Fig. 4a, green line) was not observed in the experiments. In fact, the measured profile suggests a much more divergent velocity field. To match the measured velocity profile, the shape of the fan had to be changed to arc (as illustrated in Fig. 2, velocity profile shown in Fig.4a, red line). To improve the efficiency of the mixing fans hoods were installed around each of them (current CLOUD-5 set up). However, measured velocity profiles above the mixing fans are quite similar compared to the 1-fan configuration without a hood (CLOUD-1, Fig.4b), indicating that the effect of the hoods is only small.

In Fig. 5 cross sectional profiles of the velocity magnitude are presented. The data visualize the jet above the flat fan (Fig. 5a) and the much more divergent flow field of the adjusted arc-fan simulation (Fig. 5b). Furthermore, it is shown that the upper half of the tank is almost not influenced by the arc shaped fan, as the velocity is almost zero in this part of the chamber. The turbulent intensity around the fan is much larger than for the flat fan approach, but turbulent mixing is limited to the region next to the fan (not shown here). It can be concluded that to mix the tank properly under realistic conditions (arc fan) there is a need for a second fan. In agreement, the simulated flow field for a 2-fan configuration indicates that the whole tank is mixed by such a set up (Fig. 5c). Finally, results in Fig. 5d illustrate the simulated flow field for a 2-fan configuration adjusted to the improved CLOUD-5 set up (with hoods), showing that the mixing fans still produce a divergent flow field. The low efficiency of the hoods is caused by the overall low flow velocities in the chamber. 

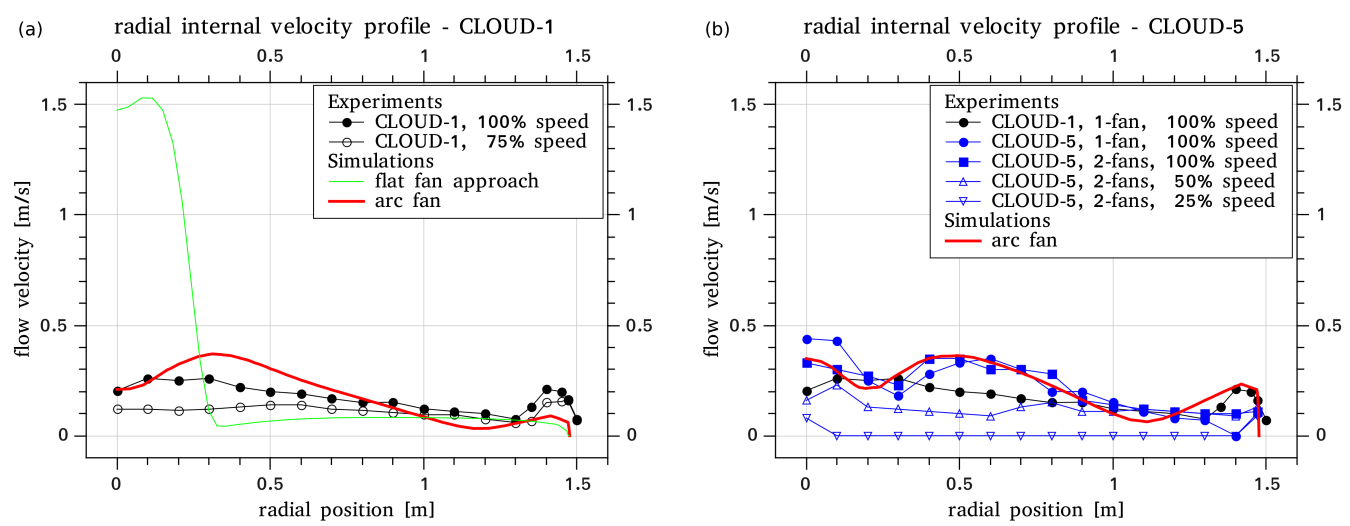

Fig. 4. Measured internal air velocity $50 \mathrm{~cm}$ above the fan (black and blue dots) compared to simulation results. The Fig. shows results for a 1-fan configuration (CLOUD-1, (a)) and a 2-fan configuration with hoods around the fans (CLOUD-5, (b)). The flow direction was not measured, but probably has large azimuthal and radial components, especially in the outer region. Different shapes of the zero thickness pressure jump layer (representing the mixing fan) result in different velocity profiles. A flat fan configuration results in a velocity profile significantly different from experimental data (green line). To match the experimental data, arc shaped layers are necessary (red line).
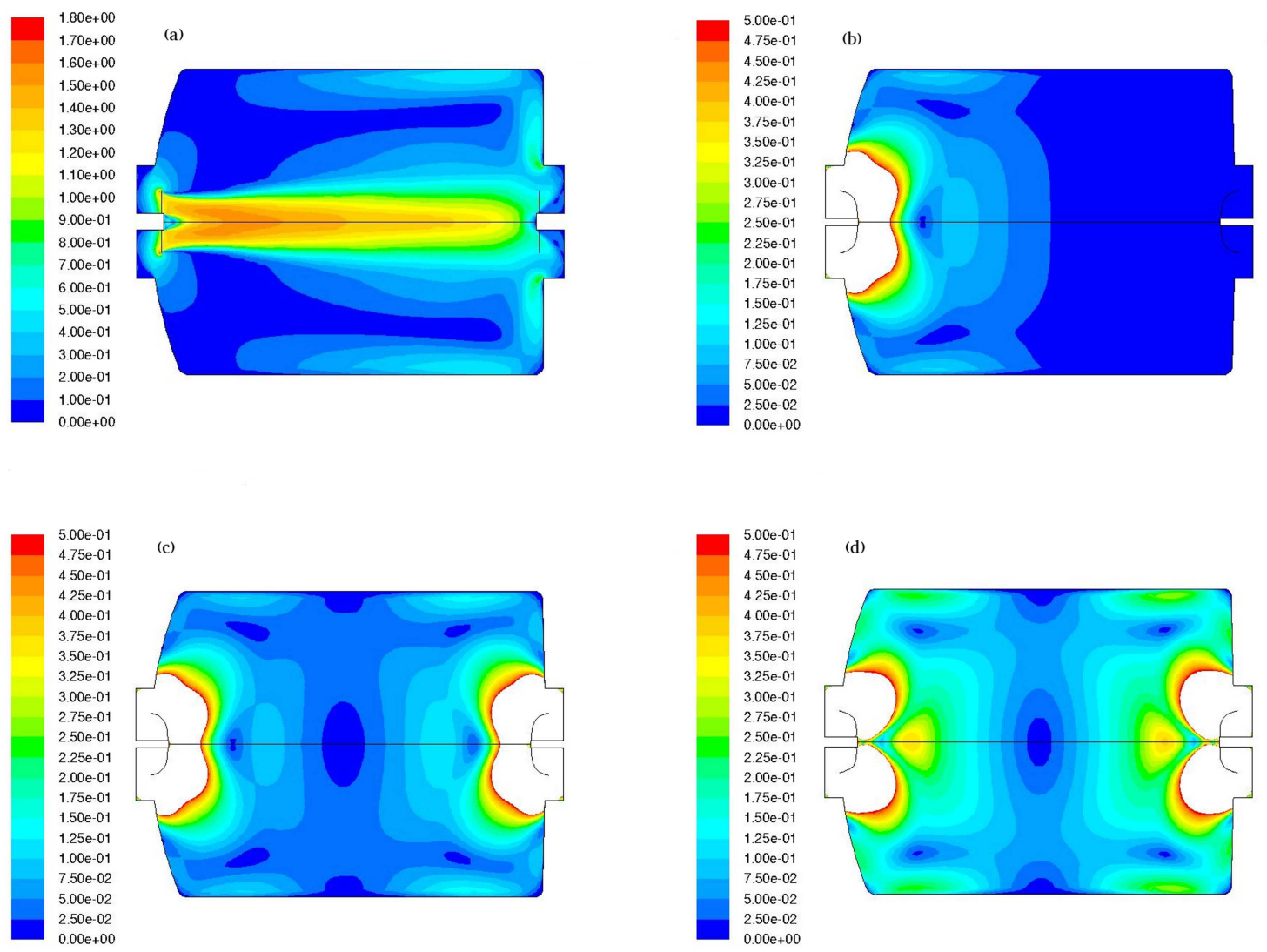

Fig. 5. Calculated cross sectional profiles of the velocity magnitude. (a) 1-fan configuration with flat fan approach, (b) 1-fan configuration with modified arc shaped pressure jump layer adjusted to the measured velocity profile $50 \mathrm{~cm}$ above the mixing fan (CLOUD-1), (c) 2 -fan configuration with fan settings as used in (b) and (d) 2-fan configuration adjusted to velocity profile of the CLOUD-5 set up (with hoods around the fans). 


\section{Results and discussion}

\section{1 $\mathrm{H}_{2} \mathrm{SO}_{4}$ lifetime experiments}

\subsubsection{Description and experimental data}

Due to molecular and turbulent vapor mass diffusion, $\mathrm{H}_{2} \mathrm{SO}_{4}$ is continuously lost to the wall. If there is no source, successive $\mathrm{H}_{2} \mathrm{SO}_{4}$ measurements allow to determine the wall losses of $\mathrm{H}_{2} \mathrm{SO}_{4}$, which depend on $\mathrm{H}_{2} \mathrm{SO}_{4}$ concentration, thermodynamic conditions and fan speed. For a proper representation of the flow field in the model (as discussed above), and suitable vapor diffusion coefficients, the numerical simulations should match the experimental data. The experiments were therefore used to validate the numerical description of the CLOUD chamber in the CLOUD-FPM model.

For the $\mathrm{H}_{2} \mathrm{SO}_{4}$ lifetime experiments, the chamber was continuously fed with the $\mathrm{H}_{2} \mathrm{SO}_{4}$ precursor gases (ozone, $\mathrm{SO}_{2}$ and water vapor). $\mathrm{H}_{2} \mathrm{SO}_{4}$ then was produced via ozone photolysis ( $\mathrm{OH}$ production) and reaction with $\mathrm{SO}_{2}$. After a certain period of time, $\mathrm{H}_{2} \mathrm{SO}_{4}$ production and loss to the wall were in equilibrium, resulting in a quasi constant $\mathrm{H}_{2} \mathrm{SO}_{4}$ concentration. After switching off the UV-illumination system, the $\mathrm{H}_{2} \mathrm{SO}_{4}$ production was stopped. The subsequent decrease of $\mathrm{H}_{2} \mathrm{SO}_{4}$ due to the transport to the wall was recorded outside of the boundary layer (thickness about 10 to $20 \mathrm{~cm}$ ) at one sampling line of the tank. $\mathrm{H}_{2} \mathrm{SO}_{4}$ was measured by a chemical ionization mass spectrometer acquired from THS instruments. The basic instrument design and the method for measuring sulfuric acid has been described in detail elsewhere (Eisele and Tanner, 1993; Berresheim et al., 2000).

The temporal decrease of the $\mathrm{H}_{2} \mathrm{SO}_{4}$ concentration for such an experiment using a 1-fan configuration is shown in Fig. 6a (black line). The $\mathrm{x}$-axis gives the running time and the $y$-axis the $\mathrm{H}_{2} \mathrm{SO}_{4}$ concentration. Thereby, the time axis was shifted so that the $\mathrm{H}_{2} \mathrm{SO}_{4}$ decrease starts at the zero line. Figure 6a shows that, at the sampling point, the $\mathrm{H}_{2} \mathrm{SO}_{4}$ concentration is reduced by more than 90 percent after $15 \mathrm{~min}$.

The experimental uncertainties of gaseous $\mathrm{H}_{2} \mathrm{SO}_{4}$ concentration measurements are about a factor of 2 . On the other hand, observed short term fluctuations of the $\mathrm{H}_{2} \mathrm{SO}_{4}$ concentrations, which represent the combination of instrumental noise and local fluctuations in the small sampling volume, were much smaller (less than 20 percent, see Fig. 6). It can be concluded that the measurement uncertainties might influence the (initial) average $\mathrm{H}_{2} \mathrm{SO}_{4}$ concentration of the experiment, but did not affect the temporal characteristics of the $\mathrm{H}_{2} \mathrm{SO}_{4}$ concentrations at the sampling point, as well as the comparison with the modeling data.

\subsubsection{Simulation results}

For the CLOUD-FPM simulations, suitable initial and boundary conditions must be chosen. All thermodynamic conditions (e.g., $T, \mathrm{RH}$ ) were adjusted to values equal to those in the experiments $(T=291.65 \mathrm{~K}, \mathrm{RH}=38 \%)$. The $\mathrm{H}_{2} \mathrm{SO}_{4}$ concentration was prescribed as initial value. Thereby, a homogeneous distribution was assumed.

Typical concentrations of $\mathrm{H}_{2} \mathrm{SO}_{4}$ in the CLOUD experiments are in the order of $10^{6} \mathrm{~cm}^{-3}$ to $10^{8} \mathrm{~cm}^{-3}$, corresponding to a $\mathrm{H}_{2} \mathrm{SO}_{4}$ mass in the order of $10^{-12} \mathrm{~kg}$ up to $10^{-10} \mathrm{~kg}$ for the whole tank. Due to the small total amount of $\mathrm{H}_{2} \mathrm{SO}_{4}$, it is a suitable assumption to consider the tank's wall as an infinite sink for $\mathrm{H}_{2} \mathrm{SO}_{4}$. In the model this was done by defining a $\mathrm{H}_{2} \mathrm{SO}_{4}$ mass fraction of zero at the wall. Sources and additional sinks (particle nucleation) for $\mathrm{H}_{2} \mathrm{SO}_{4}$ were excluded in the simulation, because particle nucleation rates are negligible at $\mathrm{H}_{2} \mathrm{SO}_{4}$ concentrations used in these experiments (Kirkby et al., 2011).

Furthermore, binary diffusion coefficients of $0.09 \mathrm{~cm}^{2} \mathrm{~s}^{-1}$ $\left(\mathrm{H}_{2} \mathrm{SO}_{4}\right.$ in air) and $0.06 \mathrm{~cm}^{2} \mathrm{~s}^{-1}\left(\mathrm{H}_{2} \mathrm{SO}_{4}\right.$ in $\left.\mathrm{H}_{2} \mathrm{O}\right)$ were applied in the simulations (Marti et al., 1997; Hanson and Eisele, 2000; Brus et al., 2010). These values are comparable to values determined using the methods of Fuller (FSG, Fuller et al., 1966), FSG-LaBas (Lyman, 1990) or Wilcke and Lee (WL, Wilke and Lee, 1955), which yield $0.11 \mathrm{~m}^{2} \mathrm{~s}^{-1}$, $0.093 \mathrm{~m}^{2} \mathrm{~s}^{-1}$, respectively $0.1 \mathrm{~m}^{2} \mathrm{~s}^{-1}$.

To evaluate the mixing state, volume average values and standard deviations of the $\mathrm{H}_{2} \mathrm{SO}_{4}$ concentrations were computed and compared to the experimental data (Fig. 6). The standard deviations represent a measure for the inhomogeneity in the CLOUD tank and were calculated as:

$\sigma_{\mathrm{H}_{2} \mathrm{SO}_{4}}=\sqrt{\frac{\sum_{\text {cell=1 }}^{N} V_{\text {cell }}\left(\rho_{\mathrm{H}_{2} \mathrm{SO}_{4}, \text { cell }}-\rho_{\mathrm{H}_{2} \mathrm{SO}_{4}, \text { mean }}\right)^{2}}{\sum_{\text {cell }=1}^{N} V_{\text {cell }}}}$

where $\rho_{\mathrm{H}_{2} \mathrm{SO}_{4} \text {, cell }}$ is the $\mathrm{H}_{2} \mathrm{SO}_{4}$ concentration in the actual

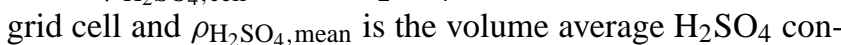
centration.

Figure 6a shows that for the 1-fan configuration the calculated concentration at the sampling volume (red dotted line) is in good agreement with the experimental data. Calculated volume average concentrations are clearly above this values (red solid line). However, in the range of the calculated standard deviations (light gray area), the mean values also agree with the measurements. Since the concentration a the sampling volume is not representative for the whole tank, the results again indicate that the tank is not well mixed by a 1 -fan configuration. Considering a 2 -fan configuration, calculated standard deviations of the $\mathrm{H}_{2} \mathrm{SO}_{4}$ concentration are much smaller (Fig. 6b). On the other hand, the wall losses are larger compared to the 1-fan set up. But also for the 2-fan set up, the agreement between experimental data and simulation results is good.

In simulations shown above, the $\mathrm{H}_{2} \mathrm{SO}_{4}$ concentration was initially defined. In additional simulations, the production of $\mathrm{H}_{2} \mathrm{SO}_{4}$ in the tank was considered. Because of the quasi constant concentrations of the precursor gases during the time scale of a typical experiment (max. several hours), the production rate was assumed to be constant with respect to time. 


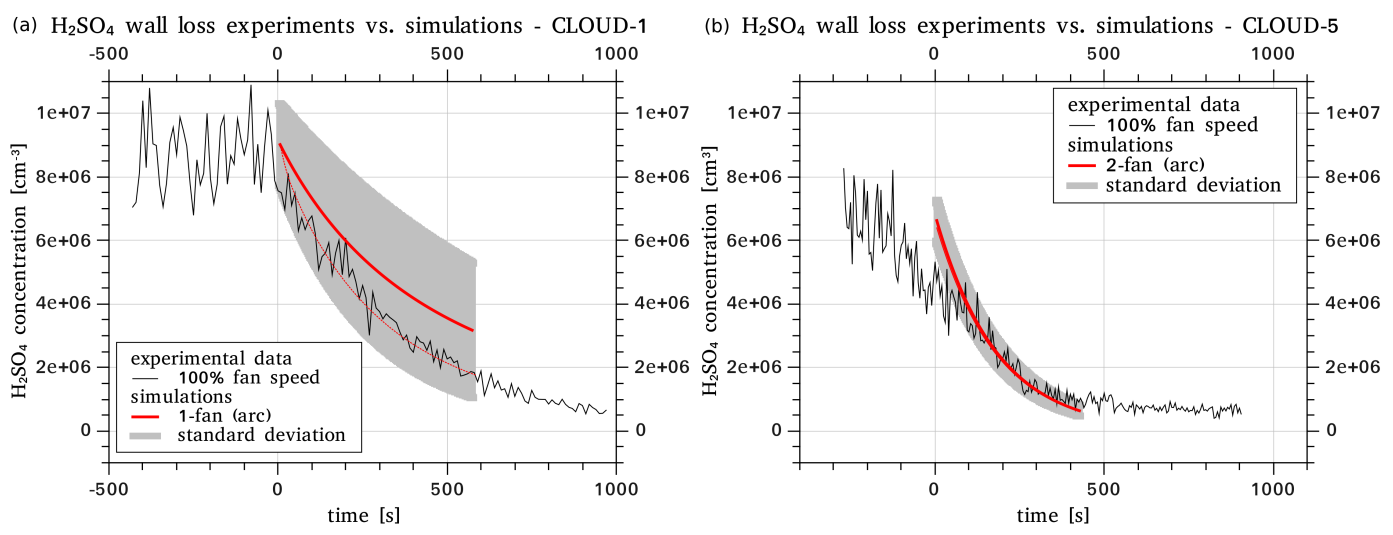

Fig. 6. $\mathrm{H}_{2} \mathrm{SO}_{4}$ lifetime experiments compared to numerical simulations for a 1-fan configuration (CLOUD-1, (a)) and a 2-fan configuration with hoods around the fans (CLOUD-5, (b)). The blue line for a 2-fan simulation (also arc shaped). The dotted lines are the results at the assumed sampling spot, the solid lines are calculated volume average values. The gray areas standard deviations, calculated for the average values.

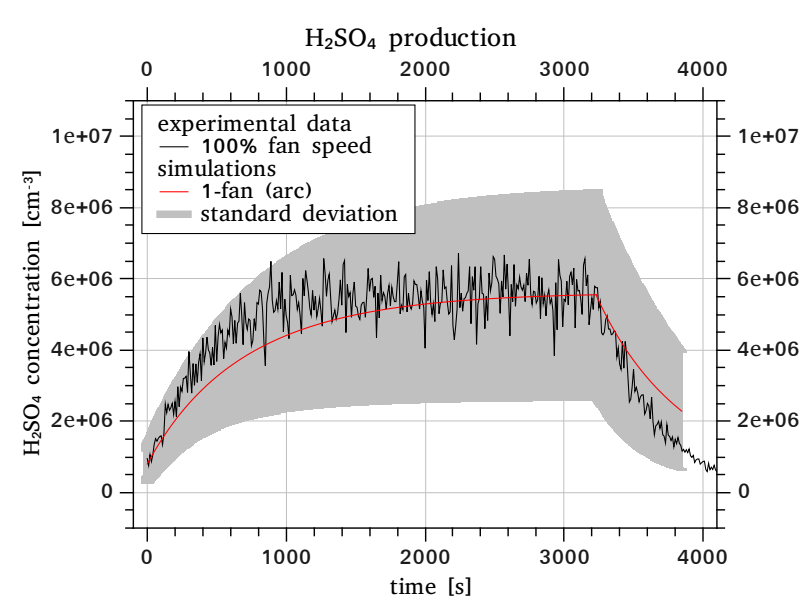

Fig. 7. Calculated $\mathrm{H}_{2} \mathrm{SO}_{4}$ concentration with constant $\mathrm{H}_{2} \mathrm{SO}_{4}$ production rate in comparison to experimental CLOUD-1 data (1-fan configuration). The source rate was $1.0 \times 10^{4} \mathrm{~cm}^{-3} \mathrm{~s}^{-1}$.

Also for that reason and to reduce the computational costs, the calculation of the chemical reactions was left out of the simulations. It was further assumed that the $\mathrm{H}_{2} \mathrm{SO}_{4}$ production only takes place in the (with high intensity) UV-light illuminated part of the tank (Fig. 3, red and yellow colored areas).

The $\mathrm{H}_{2} \mathrm{SO}_{4}$ source rates were estimated from the CLOUD experiments and span about two orders of magnitude in the range between about $10^{4} \mathrm{~cm}^{-3} \mathrm{~s}^{-1}$ and $10^{6} \mathrm{~cm}^{-3} \mathrm{~s}^{-1}$. Experimental data compared to simulation results assuming a constant source rate of $1 \times 10^{4} \mathrm{~cm}^{-3} \mathrm{~s}^{-1}$ are exemplarily shown in Fig. 7. Within the calculated standard deviation modeled and measured $\mathrm{H}_{2} \mathrm{SO}_{4}$ concentrations are in agreement, indicating that the simple approach of a constant
Table 1. 1/e volume-to-surface exchange times for an instantaneous change of wall temperature or water mass fraction for different fan configurations.

\begin{tabular}{ccccc}
\hline \multirow{2}{*}{ Configuration } & \multicolumn{2}{c}{$\begin{array}{c}T_{\text {wall }} \\
291.65 \mathrm{~K} \rightarrow 271.65 \mathrm{~K}\end{array}$} & $\begin{array}{c}x_{\mathrm{H}_{2} \mathrm{O} \text {, wall }} \\
0.005 \rightarrow 0.02\end{array}$ \\
\hline & $t_{/ \mathrm{e}}[\mathrm{s}]$ & $\Delta \bar{T}_{\max }[K]$ & $t_{\max }[\mathrm{s}]$ & $t_{/ \mathrm{e}}[\mathrm{s}]$ \\
\hline $1 \times$ fan (flat) & 184 & 1.88 & 45 & \\
$2 \times$ fan (flat) & 151 & 1.61 & 8 & \\
$1 \times$ fan (arc) & 222 & 3.03 & 282 & 287 \\
$2 \times$ fan (arc) & 100 & 2.00 & 21 & 118 \\
\hline
\end{tabular}

$\mathrm{H}_{2} \mathrm{SO}_{4}$ production rate gives proper results. Again, the large standard deviations indicate a not well mixed tank for the 1fan configuration investigated here.

\subsection{Mixing of the CLOUD tank's contents}

Time resolved simulations were carried out to estimate time scales for mixing the tank's contents. To investigate volumeto-surface exchange, the response of the system to an instantaneous change of (a) the wall temperature by $20 \mathrm{~K}(291.65$ to $271.65 \mathrm{~K}$ ), and (b) the water mass fraction at the wall by 0.015 (from 0.05 to 0.20 ) was simulated for both, the 1-fan and the 2-fan configuration. Fan shape and pressure jump settings were the same as for the $\mathrm{H}_{2} \mathrm{SO}_{4}$ lifetime experiments described above. Simulation results of the temperature jump are shown in Fig. 8a and b. The corresponding wall exchange times to reduce the difference between wall and tank's average value to $1 / \mathrm{e}$ of the initial value, called 1/e time in the following, are about $100 \mathrm{~s}$ for the 1 -fan and $220 \mathrm{~s}$ for the 2fan set up (see also Table 1). This means, the second fan reduces the mixing time by a factor of more than two. 

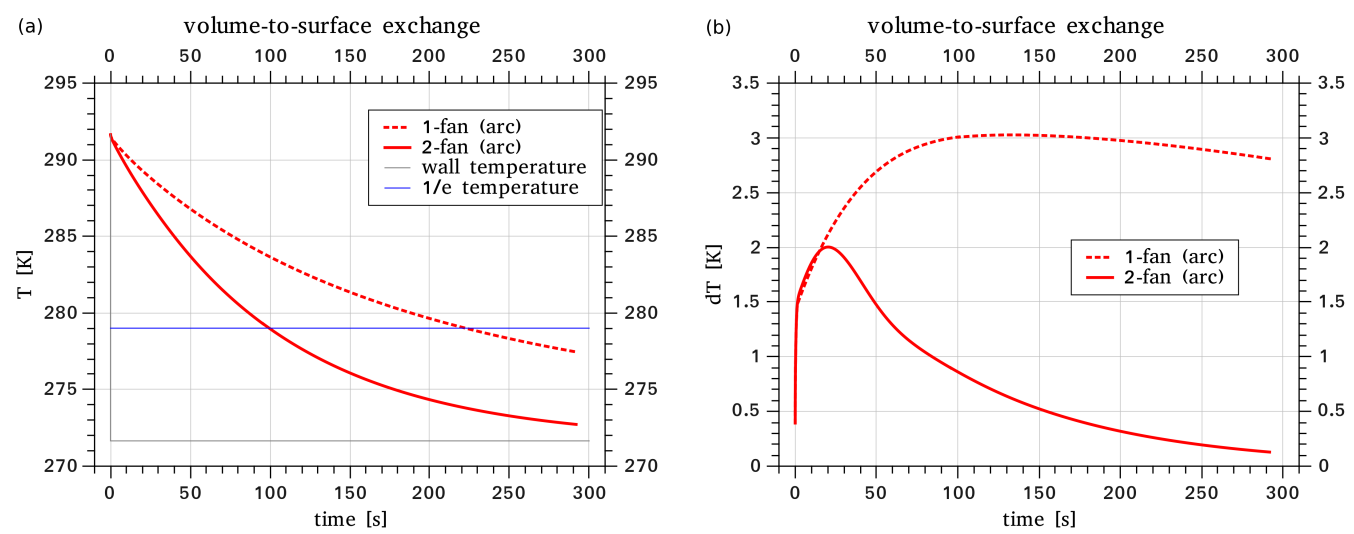

Fig. 8. Results of the simulations investigating volume-to-surface exchange in the CLOUD chamber. Shown are the temporal development of $T$ (a) and $\delta T$ (b) for an instantaneous drop of wall temperature by $20 \mathrm{~K}$.

Similar as given for the $\mathrm{H}_{2} \mathrm{SO}_{4}$ concentration, a measure for the inhomogeneity in the tank is the volume-averaged deviation of $T_{\text {mean }}$ given by:

$\Delta \bar{T}=\sqrt{\frac{\sum_{\text {cell }=1}^{N} V_{\text {cell }}\left(T_{\text {cell }}-T_{\text {mean }}\right)^{2}}{\sum_{\text {cell }=1}^{N} V_{\text {cell }}}}$

where cell is the cell index, $V_{\text {cell }}$ is cell volume and $T_{\text {cell }}$ is cell temperature.

The volume-averaged deviation of $T_{\text {mean }}$ is shown in Fig.8b. The value is zero in the beginning, because the simulation started with the assumption of a homogeneous tank. Afterwards, it increases rapidly due to the temperature change of the wall After reaching a maximum value $\Delta T_{\text {mean }}$ decreases back to zero for long time scales. The inhomogeneity of the tank is significantly reduced, if a second fan is installed ( $\Delta T_{\text {mean }}$ reduced). Again it is obvious that the usage of only 1 -fan (arc shaped) is not suitable to provide a well mixed tank, because $\Delta T_{\text {mean }}$ values are very high and decrease very slowly compared to the 2-fan configuration.

Volume-to-surface exchange time scales for heat and mass transport processes were found to be very similar. The $1 / e$ times for an instantaneous jump of the water mass fraction at the wall are almost identical to the 1/e-times for a temperature jump and are therefore not plotted again.

\subsection{Simulation of particle nucleation and growth}

Time dependent CLOUD-FPM calculations were also carried out to simulate nucleation and growth of $\mathrm{H}_{2} \mathrm{SO}_{4}-\mathrm{H}_{2} \mathrm{O}$ particles in the CLOUD tank. The focus was on the investigation of the mixing state and not a quantitative theoretical description of the experiments. For that reason, aspects of ion induced nucleation or additional condensing gases (beside $\mathrm{H}_{2} \mathrm{SO}_{4}$ ), as supposed in Duplissy et al. (2010) (according to Nieminen et al., 2010) and also discussed in Kirkby et al., 2011, were not considered.
For the simulations a parametrization of the $\mathrm{H}_{2} \mathrm{SO}_{4}$ vapor dependent nucleation rate and the subsequent particle growth had to be included into the model. With respect to the computational effort, classical nucleation theory is very expensive. Simplified parametrizations of nucleation rate $J$ are based on the equation (e.g., Kulmala et al., 2004; McMurry, 1980) :

$J=K \cdot[\mathrm{conc}]^{A}$

with the concentration of the considered nucleating vapor [conc], and the fitting parameters $K$ (kinetic coefficient) and $A$ (exponential term), derived from experiments (e.g., Berndt et al., 2006; Kuang et al., 2008; Sihto et al., 2006; Riipinen et al., 2007). For simulations shown in this study, $A$ and $K$ were adjusted to data published in Kirkby et al. (2011) (neutral case) resulting in values $A=3$ and $K=$ $0.8 \times 10^{-26} \mathrm{~cm}^{3} \mathrm{~s}^{-1}$.

Particle growth of the freshly nucleated particles was described by a simple growth law given by Seinfeld and Pandis (1997). Applying this growth law, there is no kinetic description of the particle growth with respect to water. This means, concerning water the particles are always assumed to be in thermodynamical equilibrium. The growth law is given by:

$\frac{d D_{p}}{d t}=\frac{M_{s} \bar{c} \alpha\left(C_{\mathrm{vap}}-C_{\mathrm{eq}}\right)}{2 \rho} W R$

where $D_{p}$ is particle diameter, $\rho$ is particle density, $M_{s}$ is molar weight of $\mathrm{H}_{2} \mathrm{SO}_{4}, \bar{c}$ is the mean molecular velocity of $\mathrm{H}_{2} \mathrm{SO}_{4}$ (assumed as $333 \mathrm{~m} \mathrm{~s}^{-1}$ ), $\alpha$ is the mass transfer accommodation coefficient (assumed to be 1), $C_{\text {vap }}$ is the $\mathrm{H}_{2} \mathrm{SO}_{4}$ concentration, $C_{\text {eq }}$ is the equilibrium concentration of $\mathrm{H}_{2} \mathrm{SO}_{4}$ (assumed to be zero here), and $W R$ is the ratio of wet to dry particle diameter (dry: only $\mathrm{H}_{2} \mathrm{SO}_{4}$ ). Neglecting the Kelvin term, this ratio only depends on RH (Herrmann et al., 2010). It was calculated by a linear fitting equation according to vapor pressure values given in Tabazadeh et al. (1997). The particle number size distribution was described by a single mode log-normal distribution. 

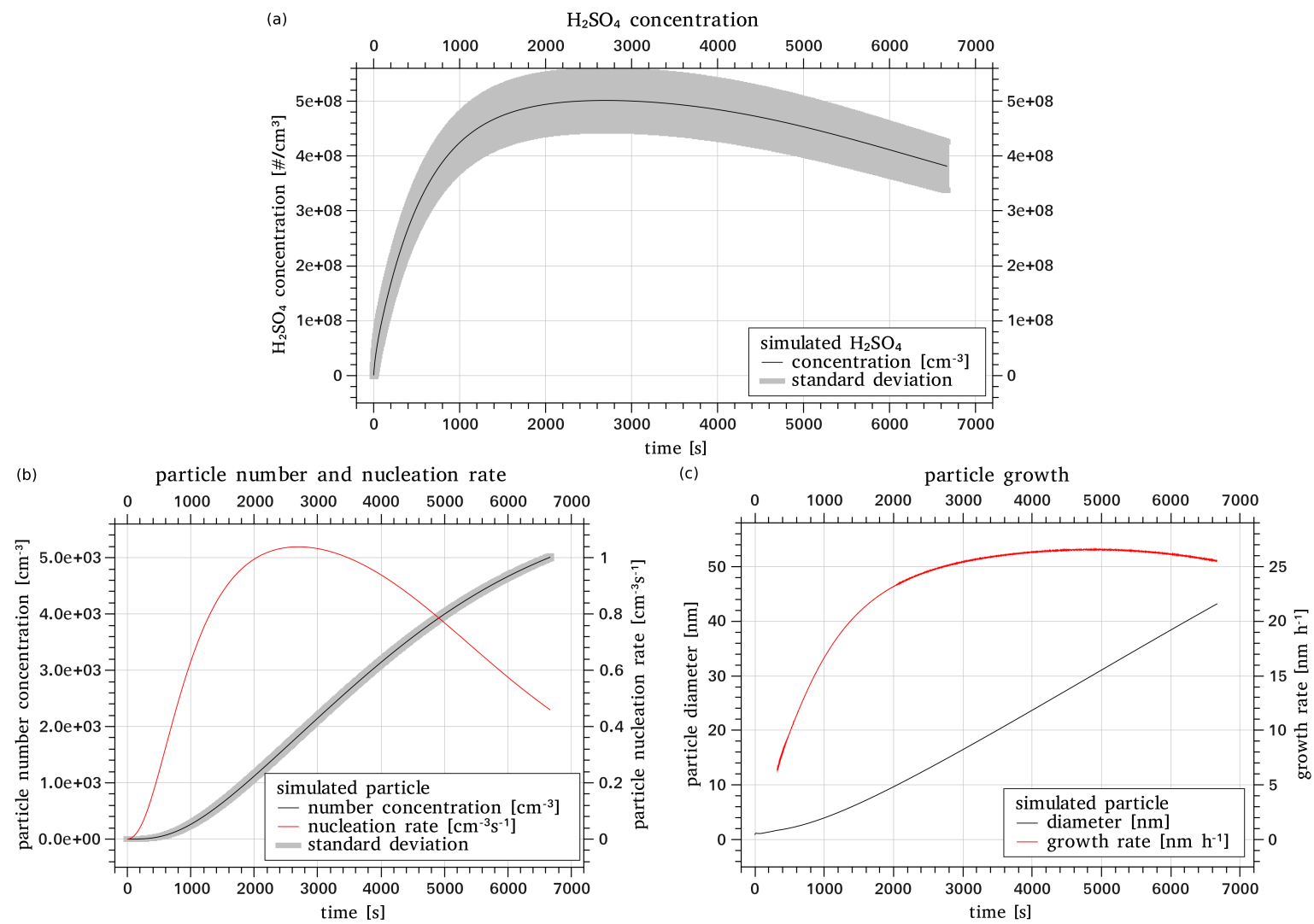

Fig. 9. Results of a simulation including particle nucleation and growth. Shown are calculated mean $\mathrm{H}_{2} \mathrm{SO}_{4}$ concentration (a), particle number concentration and nucleation rates (b), and mean particle size and growth rates (c). Details are given in the text.

The simulation shown here was done for a 2-fan configuration with arc shaped pressure jump layers as determined above. Assuming a $\mathrm{H}_{2} \mathrm{SO}_{4}$ production rate of $2.5 \times 10^{6} \mathrm{~cm}^{-3} \mathrm{~s}^{-1}$, the resulting maximum $\mathrm{H}_{2} \mathrm{SO}_{4}$ concentration was about $5 \times 10^{8} \mathrm{~cm}^{-3}$ (see Fig. 9a). After reaching its maximum, the average $\mathrm{H}_{2} \mathrm{SO}_{4}$ concentration decreases again due to the increasing amount of $\mathrm{H}_{2} \mathrm{SO}_{4}$ transferred to the particle phase by particle nucleation and condensational growth. According to Kirkby et al. (2011), particle nucleation rates were up to about $1 \mathrm{~cm}^{-3} \mathrm{~s}^{-1}$ (Fig. 9b). Volume average particle diameters plotted in Fig. 9c show that particle growth rates up to $25-30 \mathrm{~nm} \mathrm{~h}^{-1}$ were calculated.

As shown by the included (small) standard deviation of the particle number (Fig. 9b), the particles were also found to be quite homogeneously distributed over the tank's volume for this fan configuration. Furthermore, mean particle size and sigma of the log-normal distribution are also almost constant in the whole tank. Thus, the tank can be considered quite well mixed also for the freshly nucleated $\mathrm{H}_{2} \mathrm{SO}_{4}$ particles, if a suitable fan configuration, as given by the 2 -fan set up, is applied.

\section{Conclusions}

The CLOUD-FPM model was applied to conduct numerical simulations of the CLOUD tank $\left(26.1 \mathrm{~m}^{3}\right)$ established at CERN (Switzerland). In the simulations the coupled fields of temperature, saturation ratio, flow velocity, vapor species and particle number size distribution were calculated.

In the model, the CLOUD chamber was described by a 2-D axis-symmetric grid. The description of the mixing fans were realized via polynomial pressure jump settings at zero thickness layers. For a suitable prediction of the flow field, the model was compared with measured velocity profiles. With adjusted fan settings, it was found that the mixing fans produce a divergent flow field with only low volume average velocity magnitudes for fan speeds used in the experiments. Considering a 1-fan configuration the simulations show that the second half of the chamber in not influenced by the fan. Consequently, a 1-fan configuration as used in the first experiments does not provide a homogeneously mixed tank. Furthermore, the simulations suggest that the efficiency of the fan-hoods is only moderate due to the low average velocity magnitude. 
The adjusted model was applied to simulate the $\mathrm{H}_{2} \mathrm{SO}_{4}$ cycle in the CLOUD chamber including $\mathrm{H}_{2} \mathrm{SO}_{4}$ production and loss to the wall of the chamber. Thereby, $\mathrm{H}_{2} \mathrm{SO}_{4}$ production was calculated assuming constant $\mathrm{H}_{2} \mathrm{SO}_{4}$ production rates in the UV-illuminated part of the tank. Production rates were taken from experimental values. Simulated $\mathrm{H}_{2} \mathrm{SO}_{4}$ concentrations were compared to experimental data. Calculated and measured $\mathrm{H}_{2} \mathrm{SO}_{4}$ concentrations were in agreement within calculated standard deviations so that it can be concluded that the model provides an appropriate tool to evaluate the experimental data. Again, the simulations show that a 1-fan configuration does not provide a well mixed tank. On the other hand, the data suggest well mixed conditions for the 2 -fan configuration.

The mixing conditions in the CLOUD chamber were further investigated by calculating 1/e volume-to-surface exchange times for the system response to an instantaneous change of the wall temperature or water saturation ratio. These times were found in the range of few minutes. Again, a second fan significantly reduces the standard deviations and it also may decrease the volume-to-surface exchange time by a factor of 2-3 (2 min compared to $5 \mathrm{~min}$ ).

Particle nucleation and growth was also investigated in additional simulations. It was found that the mixing state of the particle number size distribution properties is quite similar to the mixing state of the gaseous components. In other words, if the tank is homogeneously mixed with respect to $\mathrm{H}_{2} \mathrm{SO}_{4}$, it can be also considered well mixed with respect to the freshly nucleated particles. In summary, it was found that an at least 2-fan configuration and sufficiently high fan speeds should be chosen to provide well mixed conditions inside of the CLOUD chamber.

Acknowledgements. We thank the German Federal Ministry of Education and Research (BMWF) for founding the modeling research presented here (project no. 01LK0902B). We further thank CERN for supporting CLOUD with important technical and financial resources, and for providing a particle beam from the CERN Proton Synchrotron. The CLOUD project further received funding from the EC Seventh Framework Programme (Marie Curie Initial Training Network "CLOUD-ITN" grant no. 215072, and ERC-Advanced "ATMNUCLE" grant no. 227463), the Swiss National Science Foundation (project nos. 206621_125025 and 206620_130527), the Academy of Finland Center of Excellence program (project no. 1118615), the Austrian Science Fund (FWF; project no. P19546 and L593), the Portuguese Foundation for Science and Technology (project no. CERN/FP/116387/2010), and the Russian Foundation for Basic Research (grant N08-02-91006CERN). We also thank J. Kirkby, K. Carslaw and J. Curtius for contributions to this manuscript.

Edited by: V.-M. Kerminen

\section{References}

Berndt, T., O. Böge, and F. Stratmann: Formation of atmospheric $\mathrm{H}_{2} \mathrm{SO}_{4} / \mathrm{H}_{2} \mathrm{O}$ particles in the absence of organics: A laboratory study, Geophys. Res. Lett., 33, L15817, doi:10.1029/2006GL026660, 2006.

Berresheim, H. and T. Elste and C. Plass-Dülmer and F. L. Eisele and D. J. Tanner: Chemical ionization mass spectrometer for long-term measurements of atmospheric $\mathrm{OH}$ and $\mathrm{H}_{2} \mathrm{SO}_{4}$, Int. J. Mass Spectrom., 202, 91-109, 2000.

Brus, D., Hyvärinen, A.-P., Viisanen, Y., Kulmala, M., and Lihavainen, H.: Homogeneous nucleation of sulfuric acid and water mixture: experimental setup and first results, Atmos. Chem. Phys., 10, 2631-2641, doi:10.5194/acp-10-2631-2010, 2010.

Carslaw, K., R. Harrison, and J. Kirkby: Cosmic rays, clouds, and climate, Science, 298, 1732-1737, 2002.

Duplissy, J., Enghoff, M. B., Aplin, K. L., Arnold, F., Aufmhoff, H., Avngaard, M., Baltensperger, U., Bondo, T., Bingham, R., Carslaw, K., Curtius, J., David, A., Fastrup, B., Gagnè, S., Hahn, F., Harrison, R. G., Kellett, B., Kirkby, J., Kulmala, M., Laakso, L., Laaksonen, A., Lillestol, E., Lockwood, M., Mäkelä, J., Makhmutov, V., Marsh, N. D., Nieminen, T., Onnela, A., Pedersen, E., Pedersen, J. O. P., Polny, J., Reichl, U., Seinfeld, J. H., Sipilä, M., Stozhkov, Y., Stratmann, F., Svensmark, H., Svensmark, J., Veenhof, R., Verheggen, B., Viisanen, Y., Wagner, P. E., Wehrle, G., Weingartner, E., Wex, H., Wilhelmsson, M., and Winkler, P. M.: Results from the CERN pilot CLOUD experiment, Atmos. Chem. Phys., 10, 1635-1647, doi:10.5194/acp-101635-2010, 2010.

Eisele, F. L. and D. J. Tanner: Measurement of the Gas-Phase Concentration of $\mathrm{H}_{2} \mathrm{SO}_{4}$ and Methane Sulfonic-Acid and Estimates of $\mathrm{H}_{2} \mathrm{SO}_{4}$ Production and Loss in the Atmosphere, J. Geophys. Res., 98, 9001-9010, 1993.

Enghoff, M. B. and Svensmark, H.: The role of atmospheric ions in aerosol nucleation - a review, Atmos. Chem. Phys., 8, 49114923, doi:10.5194/acp-8-4911-2008, 2008.

Hanson, D., and Eisele, F.: Diffusion of $\mathrm{H}_{2} \mathrm{SO}_{4}$ in humidified nitrogen: Hydrated $\mathrm{H}_{2} \mathrm{SO}_{4}$, J. Phys. Chem. A, 104, 1715-1719, 2000.

Fuller, E. N., Schettler, P. D.. and Giddings, J. C.: A new method for prediction of binary gas-phase diffusion coefficients, Ind. Eng. Chem., 58, 18-27, 1966.

Herrmann, E., Brus, D., Hyvärinen, A.-P., Stratmann, F., Wilck, M., Lihavainen, H., and Kulmala, M.: A computational fluid dynamics approach to nucleation in the water-sulfuric acid-system, J. Phys. Chem., 114, 8033-8042, 2010.

IPCC2007: Climate change 2007, Tech. rep., Cambridge University Press, 2007.

Jones, W. and Launder, B.: The prediction of laminarization with a two-equation model of turbulence, Int. J. Heat Mass Transfer, 15, 301-314, 1972.

Kirkby, J.: Cosmic rays and climate, Surv. Geophys., 28, 333-375, 2007.

Kirkby, J., Curtius, J., Almeida, J., Dunne, E., Duplissy, J., Ehrhart, S., Franchin, A., Gagne, S., Ickes, L., Kürten, A., Kupc, A., Metzger, A., Riccobono, F., Rondo, L., Schobesberger, S., Tsagkogeorgas, G., Wimmer, D., Amorim, A., Bianchi, F., Breitenlechner, M., David, A., Dommen, J., Downard, A., Ehn, M., Flagan, R. C., Haider, S., Hansel, A., Hauser, D., Jud, W., Junninen, H., Kreissl, F., Kvashin, A., Laaksonen, 
A., Lehtipalo, K., Lima, J., Lovejoy, E. R., Makhmutov, V., Mathot, S., Mikkila, J., Minginette, P., Mogo, S., Nieminen, T., Onnela, A., Pereira, P., Petaja, T., Schnitzhofer, R., Seinfeld, J. H., Sipila, M., Stozhkov, Y., Stratmann, F., Tome, A., Vanhanen, J., Viisanen, Y., Vrtala, A., Wagner, P. E., Walther, H., Weingartner, E., Wex, H., Winkler, P. M., Carslaw, K. S., Worsnop, D. R., Baltensperger, U., and Kulmala, M.: Role of sulphuric acid, ammonia and galactic cosmic rays in atmospheric aerosol nucleation., Nature, 476, 429-433, doi:10.1038/nature10343, 2011.

Kuang, C., McMurry, P., McCormick, A., and Eisele, F.: Dependence of nucleation rated on sulfuric acid vapor concentration in diverse atmospheric locations, J. Geophys. Res., 113, D10209, doi:10.1029/2007JD009253, 2008.

Kulmala, M., Vehkamki, H., Petj, T., DalMaso, M., Lauri, A., Kerminen, V.-M., Birmili, W., and McMurry, P.: Formation and growth rates of ultrafine atmospheric particles: a review of observations, J. Aerosol Sci., 35, 143-176, 2004.

Kulmala, M., Riipinen, I., Nieminen, T., Hulkkonen, M., Sogacheva, L., Manninen, H. E., Paasonen, P., Petäjä, T., Dal Maso, M., Aalto, P. P., Viljanen, A., Usoskin, I., Vainio, R., Mirme, S., Mirme, A., Minikin, A., Petzold, A., Hrrak, U., Plaß-Dülmer, C., Birmili, W., and Kerminen, V.-M.: Atmospheric data over a solar cycle: no connection between galactic cosmic rays and new particle formation, Atmos. Chem. Phys., 10, 1885-1898, doi:10.5194/acp-10-1885-2010, 2010.

Kupc, A., Amorim, A., Curtius, J., Danielczok, A., Duplissy, J., Ehrhart, S., Walther, H., Ickes, L., Kirkby, J., Kürten, A., Lima, J. M., Mathot, S., Minginette, P., Onnela, A., Rondo, L., and Wagner, P. E.: A fibre-optic UV system for $\mathrm{H}_{2} \mathrm{SO}_{4}$ production in aerosol chambers causing minimal thermal effects, J. Aerosol Sci., 42, 532-543, 2011.

Launder, B. and Spalding, D.: The numerical computation of turbulent flows, Comput. Methods Appl. Mech. Eng., 3, 269-289, 1973.

Lyman, W. J., Reehl, W. F., and Rosenblatt, D. H.: Handbook of chemical property estimation methods, American Chemical Society: Washington, DC, USA, 1990.

Marti, J., Jefferson, A., PingCai, X., Richert, C., McMurry, P., and Eisele, $\mathrm{F} .: \mathrm{H}_{2} \mathrm{SO}_{4}$ vapor pressure of sulfuric acid and ammonium sulfate solutions, J. Geophys. Res., 102, 3725-3735, 1997.
McMurry, P.: Photochemical aerosol formation from $\mathrm{so}_{2}$ : A theoretical analysis of smog chamber data, J. Colloid Interface Sci., 78, 513-527, 1980.

Nieminen, T., Lehtinen, K. E. J., and Kulmala, M.: Sub-10 nm particle growth by vapor condensation effects of vapor molecule size and particle thermal speed, Atmos. Chem. Phys., 10, 97739779, doi:10.5194/acp-10-9773-2010, 2010.

Riipinen, I., Sihto, S.-L., Kulmala, M., Arnold, F., Dal Maso, M., Birmili, W., Saarnio, K., Teinilä, K., Kerminen, V.-M., Laaksonen, A., and Lehtinen, K. E. J.: Connections between atmospheric sulphuric acid and new particle formation during QUEST III-IV campaigns in Heidelberg and Hyytilälä, Atmos. Chem. Phys., 7, 1899-1914, doi:10.5194/acp-7-1899-2007, 2007.

Schütze, M. and Stratmann, F.: Numerical simulation of cloud droplet formation in a tank, Comput. Geosci., 34, 1034-1043, 2008.

Seinfeld, J. and Pandis, S.: Atmospheric Chemistry and Physics: From air pollution to climate change, Wiley, New York, USA, 1997.

Sihto, S.-L., Kulmala, M., Kerminen, V.-M., Dal Maso, M., Petäjä, T., Riipinen, I., Korhonen, H., Arnold, F., Janson, R., Boy, M., Laaksonen, A., and Lehtinen, K. E. J.: Atmospheric sulphuric acid and aerosol formation: implications from atmospheric measurements for nucleation and early growth mechanisms, Atmos. Chem. Phys., 6, 4079-4091, doi:10.5194/acp-6-4079-2006, 2006.

Svensmark, H. and Friis-Christensen, E.: Variation of cosmic ray flux and global cloud coverage - a missing link in solar-climate relationships, J. Atm. Sol. Terr. Phys., 59, 1225-1232, 1997.

Tabazadeh, A., Toon, O., Clegg, S., and Hamill, P.: A new parameterization of $\mathrm{H}_{2} \mathrm{SO}_{4} / \mathrm{H}_{2} \mathrm{O}$ aerosol composition: Atmospheric implications, Geophys. Res. Lett., 24, 1931-1934, 1997.

Wilck, M., Stratmann, F., and Whitby, E.: A fine particle model for fluent: Description and application, in Proc. Sixth Int. Aerosol Conf., pp. 1269-1270, Chinese Association for Aerosol Research in Taiwan/International Aerosol Research Assembly, Taipei, Taiwan, 2002.

Wilke, C. R. and Lee, C. Y.: Estimation of Diffusion Coefficients for Gases and Vapors , Ind. Eng. Chem., 47, 1253-1257, 1955. 